\title{
Analisis Potensi Kebangkrutan Perusahaan Menggunakan Metode Altman Z-Score pada Perusahaan Sektor Property \& Real Estate yang Terdaftar di BEI
}

\author{
(Analysis of Bankruptcy Potential Using Altman Z-Score Method in Property \& Real \\ Estate Sector Companies Listed in IDX)
}

\author{
Damara Krishnatama*, Septarina Prita, Sudarno \\ Jurusan Akuntasi, Fakultas Ekonomi dan Bisnis, Universitas Jember (UNEJ) \\ Jln. Kalimantan 37, Jember 68121 \\ E-mail: damara.krishna@yahoo.com
}

\begin{abstract}
Abstrak
Altman Z-Score merupakan medote yang digunakan untuk menganalisis potensi kebangkrutan suatu perusahaan. Z-Score diklaim mampu mendeteksi kebangkrutan perusahaan dengan tingkat akurasi yang tinggi dan metode ini ternyata juga sangat populer digunakan. Altman menggunakan perhitungan melalui 5 rasio keuangan yang ada dalam formula, yaitu Net Working Capital to Total Assets, Retained Earning to Total Assets, Earning Before Interest and Taxes to Total Assets, Market Value of Equity to Book Value of Debt dan Sales to Total Assets. Atas pertimbangan kriteria pemilihan obyek yang telah ditentukan, peneliti melakukan penelitian terhadap 11 perusahaan sektor Property \& Real Estate yang listing di Bursa Efek Indonesia. Metode ini menggolongkan kondisi suatu perusahaan ke dalam 3 golongan, yaitu krisis, grey area dan sehat. Adapun hasil dari penelitian ini yang telah dilakukan pada 11 perusahaan adalah terdapat 3 perusahaan dengan kondisi krisis, 4 perusahaan dengan kondisi grey area, dan 4 perusahaan dengan kondisi sehat. Dengan demikian, diharapkan bagi perusahaan yang berada pada kondisi krisis dan grey area agar lebih koreksi dan dapat membenahi permasalahan yang ada guna mencapai kelangsungan hidup perusahan yang lebih sehat kedepannya.
\end{abstract}

Kata kunci : Altman Z-Score, Kebangkrutan, Laporan Keuagan, Property \& Real Estate, Bursa Efek Indonesia (BEI).

\section{Abstract}

Altman Z-Score is a method used to analyze the potential bankruptcy of a company. Z-Score is claimed to be able to detect corporate bankruptcy with a high degree of accuracy and this method was also very popularly used. Altman uses calculations through the five financial ratios in the formula, namely Net Working Capital to Total Assets, Retained Earning to Total Assets, Earning Before Interest and Taxes to Total Assets, Market Value of Equity to Book Value of Debt and Sales to Total Assets. On the consideration of the criteria for the selection of the object that has been determined, the researcher conducts research on 11 companies of Property \& Real Estate sector listing on Indonesia Stock Exchange. This method classifies the condition of a company into 3 groups, namely crisis, gray area and healthy. The results of this study that has been done on 11 companies are 3 companies with crisis conditions, 4 companies with gray area conditions, and 4 companies with healthy conditions. Thus, it is expected for companies that are in crisis and gray area conditions to be more correction and can fix the existing problems in order to achieve the viability of a healthier company going forward.

Keywords: Altman Z-Score, Bankruptcy, Financial Report, Property \& Real Estate, Indonesia Stock Exchange (IDX).

\section{Pendahuluan}

Kebangkrutan merupakan kondisi dimana perusahaan mengalami kegagalan dalam beroperasi, menyebabkan ketidakmampuan membiayai operasionalnya secara normal dan ketidakmampuan membayar berbagai kewajiban mereka. Kebangkrutan pada umumnya disebabkan oleh kegagalan keuangan atau financial distress, dimana perusahaan tidak dapat mengelolah keuangannya dengan baik. Setiap perusahaan memiliki kewajiban untuk dapat menjalankan operasinya dengan baik dengan strategi yang tepat agar dapat menjaga keberlangsungan hidupnya.

Perusahaan merupakan salah satu pelaku dalam perekonomian Indonesia. Perusahaan satu dengan lainnya akan saling bersaing untuk menjadi yang terbaik. Perusahaan yang bereputasi baik dan sudah go public umumnya tercatat di Bursa Efek Indonesia (BEI). Hingga saat ini sudah banyak perusahaan yang listing atau namanya tercatat di Bursa Efek Indonesia (BEI). Menurut catatan Bursa Efek Indonesia
(BEI), hingga tahun 2017 terdapat 491 perusahaan yang telah listing di BEI.

Perusahaan merupakan salah satu pelaku dalam perekonomian Indonesia. Perusahaan satu dengan lainnya akan saling bersaing untuk menjadi yang terbaik. Perusahaan yang bereputasi baik dan sudah go public umumnya tercatat di Bursa Efek Indonesia (BEI). Hingga saat ini sudah banyak perusahaan yang listing atau namanya tercatat di Bursa Efek Indonesia (BEI). Menurut catatan Bursa Efek Indonesia (BEI), hingga tahun 2017 terdapat 491 perusahaan yang telah listing di BEI.

Indonesia dalam menjalankan perekonomiannya tidak selalu berjalan dengan mulus, dengan adanya kegagalan perusahaan dalam beroperasi menjadikan salah satu penyebab perekonomian tidak stabil. Jika perusahaan yang cukup baik akan listing di BEI, maka perusahaan yang mengalami kegagalan akan delisting atau pencatatan namanya dihapus dari BEI. Perusahaan delisting karena berbagai pertimbangan, antara lain perusahaan mengalami pembubaran, merger

\footnotetext{
* Corresponding author
} 
dengan perusahaan lain, dan yang paling umum adalah terkena financial distress sehingga menyebabkan kebangkrutan perusahaan.

Berdasarkan data 5 tahun terakhir, peneliti mencoba mengumpulkan informasi terkait perusahaan-perusahaan yang mengalami financial distress yang mengakibatkan delisting dari BEI. Peneliti juga menyertakan tahun berjalan 2017 sebagai data ter-update, meskipun tahun 2017 belum berakhir sepenuhnya. Berikut daftar perusahaan yang di delisting dalam 5 tahun terakhir dapat dilihat dari tabel dibawah ini.

Tabel 1. Daftar Perusahaan Delisting dalam 5 Tahun Terakhir (2011-2017)

\begin{tabular}{lcccccccc}
\hline \multicolumn{1}{c}{ Sektor } & 201 & 201 & 201 & 201 & 201 & 201 & 201 & Tot \\
& 1 & 2 & 3 & 4 & 5 & 6 & 7 & al \\
\hline $\begin{array}{l}\text { Property \& } \\
\text { real estate }\end{array}$ & 1 & 1 & 1 & & & & 2 & 5 \\
$\begin{array}{l}\text { Makanan \& } \\
\text { minuman }\end{array}$ & 1 & & & & 1 & & 2 \\
$\begin{array}{l}\text { Bank } \\
\text { Tekstil dan }\end{array}$ & & & 1 & & 1 & \\
garmen \\
$\begin{array}{l}\text { Tambang } \& \\
\text { batubara }\end{array}$
\end{tabular}

Sumber : www.sahamok.com, data diolah lebih lanjut oleh peneliti (2017)

Berdasarkan pengamatan tabel di atas, menunjukkan bahwa sektor property \& real estate memiliki jumlah perusahaan yang paling banyak di delisting oleh BEI, yaitu sebanyak 5 perusahaan hingga tahun berjalan 2017 ini. Adapun rincian penyebab perusahaan property \& real estate yang delisting di setiap tahunnya, yaitu terkena financial distress di perusahaan New Century Development (tahun 2012), perusahaan Suryainti Permata (tahun 2013), perusahaan Panca Wirasakti (tahun 2013) dan merger perusahaan Ciputra Surya \& Ciputra Properti (tahun 2017) karena tidak efisiensinya kegiatan operasional. Dengan pertimbangan yang telah diuraikan, peneliti akhirnya menetapkan obyek perusahaan yang berada pada sektor property \& real estate.

Perusahaan dalam menjalankan operasinya tidak serta merta hanya menjalankan operasinya saja dengan strategi yang baik, melainkan perusahaan juga harus memikirkan dampak buruk dari strateginya dengan harus selalu mewaspadai adanya potensi kebangkrutan sedini mungkin. Resiko kebangkrutan bagi perusahaan dapat dilihat dan diukur melalui laporan keuangan, dengan cara melakukan analisis rasio terhadap laporan keuangan yang dikeluarkan oleh perusahaan yang bersangkutan (Sondakh, Murni \& Mandagie, 2014:2). Laporan keuangan yang diterbitkan oleh perusahaan merupakan salah satu sumber informasi mengenai posisi keuangan perusahaan. Dengan informasi dari laporan keuangan dapat dilakukan analisis potensi kebangkrutan yang dapat membantu perusahaan dalam mengambil keputusan kedepannya.

Berbagai analisis telah dilakukan oleh banyak peneliti untuk memprediksi potensi kebangkrutan perusahaan di masa depan. Terdapat 3 metode analisis dalam memprediksi kebangkrutan perusahaan, yaitu Zmijewski, Altman Z-score, dan Springate. Fitriyanti dan Yunita (2014) pernah melakukan penelitian menggunakan 3 metode analisis tersebut, hasil analisis yang diperoleh adalah metode Altman Z-score merupakan metode analisis yang memiliki tingkat akurasi paling tinggi dan paling tepat untuk digunakan. Altman Z-score bekerja secara kompleks dengan berfokus pada lima rasio keuangan yang ada yaitu Modal Kerja terhadap Total Aktiva, Saldo Laba terhadap Total Aktiva, EBIT terhadap Total Aktiva, Nilai Pasar Ekuitas terhadap Total Hutang, dan Penjualan terhadap Total Aktiva. Rasiorasio tersebut menghubungkan antara satu jumlah tertentu dengan jumlah yang lain. Metode ini juga memiliki titik cut off yang dapat mengkategorikan perusahaan pada 3 zona.

Berdasarkan latar belakang yang sudah diuraikan, peneliti mencoba merumuskan masalah dalam bentuk pertanyaan "Apakah perusahaan sektor property \& real estate yang terdaftar di BEI tahun 2016 berpotensi mengalami kebangkrutan di masa akan datang berdasarkan analisis metode Altman Z-Score?"

Tujuan penelitian ini adalah untuk memprediksi potensi kebangkrutan pada perusahaan sektor property \& real estate yang terdaftar di BEI tahun 2016 berdasarkan analisis laporan keuangan dengan menggunakan metode Altman Z-Score.

\section{Metode}

\section{Rancangan Penelitian}

Penelitian ini merupakan penelitian kuantitatif dengan metode penelitian deskriptif. Melalui penelitian deskriptif, peneliti berusaha mendeskripsikan peristiwa dan kejadian yang menjadi pusat perhatian tanpa memberikan perlakukan khusus terhadap peristiwa tersebut. 


\section{Jenis dan Sumber Data}

Jenis data yang digunakan dalam penelitian ini adalah data sekunder. Data sekunder merupakan sumber data penelitian yang diperoleh peneliti secara tidak langsung melalui media perantara (diperoleh dan dicatat oleh pihak lain). Data sekunder umumnya berupa bukti, catatan atau laporan historis yang telah tersusun dalam arsip (data dokumenter) yang dipublikasikan dan tidak dipublikasikan. Dalam penelitian ini data yang digunakan adalah laporan keuangan perusahaan sektor property \& real estate yang terdaftar di BEI tahun 2016.

\section{Populasi dan Sampel}

Populasi dari penelitian ini adalah seluruh perusahaan yang berada pada sektor property \& real estate yang terdaftar di BEI. Dari keseluruhan populasi, pemilihan sampel dilakukan dengan metode cluster sampling.

Pada penelitian ini terdapat jumlah populasi dari perusahaan sektor property \& real estate sebanyak 47 perusahaan. Dari total tersebut terbagi menjadi 4 kawasan, yaitu Daerah Ibu Kota Jakarta (36), Jawa Barat (7), Jawa Timur (3) dan Sulawesi Selatan (1). Lalu berdasarkan pengamatan yang telah dilakukan peneliti melalui sejarah perusahaan property \& real estate yang delisting dari BEI selama 5 tahun terakhir, didapat kesimpulan bahwa sebagian besar perusahaan property \& real estate yang delisting berlokasi di luar Jakarta, dengan rincian sebagai berikut :

Tabel 2. Perusahaan Property \& Real Estate yang delisting (2011-2017)

\begin{tabular}{lccc}
\hline \multicolumn{1}{c}{ Nama Perusahaan } & $\begin{array}{c}\text { Tahun } \\
\text { Delisti } \\
n g\end{array}$ & Lokasi & Penyebab \\
& 2011 & Surabay & Financial \\
New Century Develop & Distress \\
Tbk & & Surabay & Financial \\
Suryainti Permata Tbk & 20112 & a & Distress \\
Panca Wirasakti Tbk & 2013 & $\begin{array}{c}\text { Tangera } \\
\text { ng }\end{array}$ & $\begin{array}{c}\text { Financial } \\
\text { Distress }\end{array}$ \\
Ciputra Property Tbk & 2017 & Jakarta & Merger \\
Ciputra Surya Tbk & 2017 & Jakarta & Merger \\
\hline
\end{tabular}

Sumber : www.sahamok.com, data diolah lebih lanjut oleh peneliti (2017)

Berdasarkan tabel diatas, maka peneliti memutuskan mengambil obyek penelitian pada perusahaan property \& real estate yang berada diluar daerah Jakarta, karena dianggap berpotensi bangkrut. Jumlah perusahaan property $\&$ real estate di luar daerah Jakarta berjumlah 11 perusahaan.

\section{Metode Analisis Data}

Analisis data dalam penelitian ini adalah dengan menggunakan metode Altman Z-Score. Metode Altman ZScore digunakan untuk menganalisis potensi kebangkrutan perusahaan melalui laporan keuangan perusahaan, dengan menggunakan 5 rasio keuangan yang ada pada formula Altman Z-Score.

\section{Hasil dan Pembahasan}

\section{Hasil Analisis Deskriptif}

Metode Altman Z-Score yang digunakan pada penelitian ini memiliki formula :

$$
Z=1,2 X 1+1,4 X 2+3,3 X 3+0,6 X 4+1,0 X 5
$$

Dimana dalam formula ini yang menjadi rasio dalam model Altman Z-Score, yaitu:

1. X1 adalah Net Working Capital to Total Assets.

$$
\text { capital }
$$

$$
\mathrm{X} 1=\quad \frac{\text { Retained earnings }}{\text { total asset }}
$$

2. X2 adalah Retained Earning to Total Assets.

$$
\mathrm{X} 2=\text { and taxes }^{\text {Earnings before interest. }} .
$$

3. X3 adalah Earning Before Interest and Taxes to Total Assets. Market value of equity

\section{book value o $\$$ fotal debts}

4. X4 adalah Market Value of Equity to Book Value of Debt.

$$
\mathrm{X} 4=\frac{\text { Sales }}{\text { total asset }}
$$

5. X5 adalah Sales to Total Assets.

$$
\mathrm{X} 5=
$$

Hasil perhitungan nilai Z-Score bisa dijelaskan sebagai berikut:

1. Jika nilai $\mathrm{Z}>2,99$ maka Perusahaan tidak mengalami masalah dengan kondisi keuangan.

2. Jika $1,81<\mathrm{Z}<2,99$ maka Perusahaan akan mengalami permasalahan keuangan jika tidak melakukan perbaikan yang berarti dalam manajemen (grey area).

3. Jika $Z<1,81$ maka Perusahaan mengalami masalah keuangan yang serius.

4. Mengevaluasi dan menyimpulkan hasil perhitungan Altman Z-Score untuk setiap perusahaan.

Untuk obyek penelitian, terdapat 11 perusahaan sektor property \& real estate yang menjadi obyek dalam penelitian dengan rincian nama dan kode sebagai berikut :

Tabel 3. Daftar Perusahaan Sektor Property \& Real Estate

\begin{tabular}{clc}
\hline No. & \multicolumn{1}{c}{ Nama Perusahaan } & Kode \\
\hline 1 & Bekasi Asri Pemula Tbk & BAPA \\
2 & Bekasi Fajar Industrial Estate Tbk & BEST \\
3 & PT Binakarya Jaya Abadi Tbk & BIKA \\
4 & Bukit Darmo Property Tbk & BKDP
\end{tabular}


5 Bumi Serpong Damai Tbk

BSDE

6 Gowa Makassar Tourism Development Tbk GMTD

7 Jaya Real Property Tbk

JRPT

8 Lamicitra Nusantara Tbk

LAMI

9 Lippo Cikarang Tbk

LPCK

10 Lippo Karawaci Tbk

LPKR

11 Pakuwon Jati Tbk

PWON

Sumber: data sekunder, 2017.

Setelah itu akan dilakukan perhitungan terhadap 5 rasio Altman Z-Score pada 11 perusahaan, berikut hasil dari perhitungan 5 rasio Altman Z-Score pada 11 perusahaan:

Tabel 4. Hasil Perhitungan Altman Z-Score pada 11 Perusahaan Sektor Property \& Real Estate

\begin{tabular}{|c|c|c|c|c|c|c|}
\hline No & Perusahaan & $\begin{array}{c}\text { Rasio } \\
\text { X1 }\end{array}$ & $\begin{array}{c}\text { Rasio } \\
\text { X2 }\end{array}$ & $\begin{array}{c}\text { Rasio } \\
\text { X3 }\end{array}$ & $\begin{array}{c}\text { Rasio } \\
\text { X4 }\end{array}$ & $\begin{array}{c}\text { Rasio } \\
\text { X5 }\end{array}$ \\
\hline 1 & BAPA & 0,40 & 0,24 & 0,01 & 0,46 & 0,19 \\
\hline 2 & BEST & 0,25 & 0,42 & 0,07 & 1,35 & 0,16 \\
\hline 3 & BIKA & 0,44 & 0,06 & $-0,03$ & 0,16 & 0,26 \\
\hline 4 & BKDP & $-0,24$ & $-0,27$ & $-0,04$ & 2,14 & 0,07 \\
\hline 5 & BSDE & 0,28 & 0,32 & 0,05 & 2,42 & 0,17 \\
\hline 6 & GMTD & 0,06 & 0,47 & 0,07 & 1,2 & 0,24 \\
\hline 7 & JRPT & $-0,01$ & 0,47 & 0,12 & 3,36 & 0,28 \\
\hline 8 & LAMI & 0,43 & 0,46 & 0,03 & 5,02 & 0,15 \\
\hline 9 & LPCK & 0,65 & 0,66 & 0,1 & 2,49 & 0,27 \\
\hline 10 & LPKR & 0,67 & 0,17 & 0,03 & 0,09 & 0,23 \\
\hline 11 & PWON & 0,07 & 0,34 & 0,08 & 2,82 & 0,23 \\
\hline \multicolumn{2}{|r|}{ Rata-rata } & 0,27 & 0,31 & 0,05 & 1,96 & 0,2 \\
\hline
\end{tabular}

Sumber : data diolah peneliti, 2017.

Setelah melakukan perhitungan secara sistematis dari 5 rasio Altman Z-Score pada 11 perusahaan property \& real estate yang terdaftar di BEI periode 2016, dilakukan perhitungan Altman Z-Score. Adapun hasil perhitungan Altman Z-Score pada 11 perusahaan property $\&$ real estate yang terdaftar di BEI periode 2016 sebagai berikut:

Tabel 5. Hasil Perhitungan Altman Z-Score pada 11 Perusahaan Sektor Property \& Real Estate

\begin{tabular}{cccccccc}
\hline $\begin{array}{c}\text { No } \\
\cdot\end{array}$ & $\begin{array}{c}\text { Perusahaa } \\
\mathrm{n}\end{array}$ & $1,2 \mathrm{X} 1$ & $1,4 \mathrm{X} 2$ & $3,3 \mathrm{X} 3$ & $0,6 \mathrm{X}$ & $1,0 \mathrm{X}$ & $\mathrm{Z}$ \\
\hline 1 & $\mathrm{BAPA}$ & 0,48 & 0,34 & 0,03 & 0,28 & 0,19 & $\begin{array}{c}1,3 \\
2\end{array}$ \\
& & & & & & & 4 \\
2 & BEST & 0,3 & 0,59 & 0,20 & 0,81 & 0,16 & $\begin{array}{c}2,0 \\
6\end{array}$ \\
& & & & & & & 6 \\
3 & BIKA & 0,53 & 0,08 & $-0,10$ & 0,10 & 0,26 & 0,8 \\
& & & & & & & 7 \\
4 & BKDP & $-0,29$ & $-0,38$ & $-0,13$ & 1,28 & 0,07 & 0,5 \\
& & & & & & & 6 \\
5 & BSDE & 0,34 & 0,45 & 0,17 & 1,45 & 0,17 & 2,5
\end{tabular}

\begin{tabular}{rrrrrrrr}
10 & LPKR & 0,80 & 0,24 & 0,10 & 0,05 & 0,23 & $\begin{array}{c}1,4 \\
3\end{array}$ \\
11 & PWON & 0,08 & 0,48 & 0,26 & 1,69 & 0,23 & $\begin{array}{c}2,7 \\
5\end{array}$ \\
\hline Rata-rata & 0,33 & 0,43 & 0,14 & 1,17 & 0,20 & $\begin{array}{c}2,2 \\
7\end{array}$ \\
\hline
\end{tabular}

Sumber : lampiran data diolah, 2017

\section{Pembahasan}

Setelah dilakukan perhitungan dengan formula Altman ZScore, maka diperoleh nilai $\mathrm{Z}$ yang merupakan hasil akhir dari analisis potensi kebangkrutan pada 11 perusahaan property \& real estate yang terdaftar di BEI periode 2016. Dengan hasil perhitungan nilai Z-Score tersebut, selanjutnya tiap perusahaan akan digolongkan ke dalam 3 kategori, yaitu krisis, grey area dan sehat.

Jika nilai $\mathrm{Z}<1,81$ maka perusahaan mengalami masalah keuangan dan dikategorikan sebagai perusahaan yang krisis, jika nilai $1,81<\mathrm{Z}<2,99$ maka perusahaan berada di tengahtengah kondisi krisis dan sehat (grey area) dan jika nilai $\mathrm{Z}>2,99$ maka perusahaan berada dalam kondisi yang sehat. Berikut penggolongan perusahaan jika dilihat dari nilai Altman Z-Score yang dihasilkan:

Tabel 6. Analisis Potensi Kebangkrutan pada 11 Perusahaan Sektor Property \& Real Estate dengan Altman ZScore

\begin{tabular}{|c|c|c|c|}
\hline No. & Perusahaan & $\begin{array}{l}\text { Nilai } \\
\text { Z }\end{array}$ & Kategori \\
\hline 1 & Bekasi Asri Pemula Tbk & 1,32 & krisis \\
\hline 2 & $\begin{array}{l}\text { Bekasi Fajar Industrial Estate } \\
\text { Tbk }\end{array}$ & 2,06 & rey area \\
\hline 3 & PT Binakarya Jaya Abadi Tbk & 0,87 & krisis \\
\hline 4 & Bukit Darmo Property Tbk & 0,56 & krisis \\
\hline 5 & Bumi Serpong Damai Tbk & 2,57 & grey area \\
\hline 6 & $\begin{array}{l}\text { Gowa Makassar Tourism } \\
\text { Development Tbk }\end{array}$ & 1,92 & grey area \\
\hline 7 & Jaya Real Property Tbk & 3,34 & sehat \\
\hline 8 & Lamicitra Nusantara Tbk & 4,42 & sehat \\
\hline 9 & Lippo Cikarang Tbk & 3,79 & sehat \\
\hline 10 & Lippo Karawaci Tbk & 1,43 & krisis \\
\hline 11 & Pakuwon Jati Tbk & 2,75 & grey area \\
\hline
\end{tabular}


Berdasarkan hasil analisis di atas, kondisi perusahaan yang mengalami kondisi krisis dideskripsikan sebagai berikut:

\section{Bekasi Asri Pemula Tbk (BAPA)}

Dari hasil analisis potensi kebangkrutan yang dilakukan dengan Altman Z-Score, didapatkan hasil bahwa perusahaan ini termasuk dalam kategori perusahaan krisis atau mengalami kesulitan keuangan yang serius dan berpotensi bangkrut. Jika dianalisis dengan melihat rasio-rasio Altman $Z$-Score, perusahaan ini memiliki nilai yang rendah pada rasio $\mathrm{X} 2, \mathrm{X} 3$ dan $\mathrm{X} 4$. Perusahaan ini memiliki nilai rasio $\mathrm{X} 2$ sebesar 0,34 dengan rata-rata 0,43 , nilai rasio $\mathrm{X} 3$ sebesar 0,03 dengan rata-rata 0,14 dan nilai rasio $\mathrm{X} 4$ sebesar 0,28 dengan rata-rata 1,17 . Pada rasio $\mathrm{X} 2$, berdasarkan informasi pada laporan keuangan perusahaan hanya memiliki saldo laba sebesar Rp 44.371.049.038, sedangkan total asetnya sebesar Rp 179.260.878.116. Lalu pada rasio X3, perusahaan ini juga hanya memiliki EBIT yang kecil, yaitu hanya sebesar Rp 1.961.065.401. Sedangkan pada rasio X4, perusahaan ini memiliki nilai rasio X4 yang rendah dikarenakan rendahnya nilai pasar ekuitas dan tingginya nilai buku utang yang dimilikinya. Nilai pasar ekuitas perusahaan hanya sebesar Rp 33.089.226.000, sedangkan nilai buku utang sebesar Rp 72.040.603.450. Nilai pasar ekuitas perusahaan ini hanya memiliki harga saham per lembar sebesar Rp 50 saja dengan saham yang beredar 661.784.520 lembar. Sedangkan pada nilai buku utang, yang membuat perusahaan ini memiliki utang cukup tinggi adalah besarnya utang pada bank, yaitu mencapai Rp 22.602.666.668.

\section{PT Binakarya Jaya Abadi Tbk (BIKA)}

Berdasarkan hasil analisis Altman Z-Score, perusahaan ini termasuk dalam kategori perusahaan krisis atau mengalami kesulitan keuangan yang serius dan berpotensi bangkrut. Perusahaan ini memiliki nilai skor $Z$ sebesar 0,87 . Jika dilihat dari nilai-nilai rasio yang ada, perusahaan ini memiliki nilai rasio $\mathrm{X} 2, \mathrm{X} 3$ dan $\mathrm{X} 4$ yang sangat rendah, bahkan rasio $\mathrm{X} 3$ bernilai negatif. Perusahaan ini memiliki nilai rasio $\mathrm{X} 2$ sebesar 0,08 dengan rata-rata 0,43 , rasio X3 sebesar $-0,10$ dengan rata-rata 0,14 dan rasio $\mathrm{X} 4$ sebesar 0,10 dengan ratarata 1,17 . Pada rasio $\mathrm{X} 2$, perusahaan ini memiliki saldo laba yang kecil dan total aset yang jauh lebih besar, sehingga menghasilkan nilai X2 kecil. Saldo laba perusahaan ini sebesar Rp 143.510.144.685 dan total asetnya adalah Rp 2.400.682.388.179. Sedangkan pada rasio X3, perusahaan ini memiliki nilai X3 yang kecil dikarenakan memiliki EBIT yang bernilai negatif, yaitu -Rp 77.013.307.787. Perusahaan ini memiliki beban-beban usaha yang cukup besar yaitu mencapai Rp 100.002.931.039, sedangkan laba usahanya sendiri hanya sebesar Rp 22.989.623.252. Lalu pada rasio $\mathrm{X} 4$, perusahaan ini memiliki nilai rasio $\mathrm{X} 4$ yang kecil karena memiliki nilau buku utang yang cukup besar, yaitu sebesar Rp 1.731.221.077.695, sedangkan nilai pasar ekuitasnya sendiri hanya sebesar Rp 278.371.600.000. Penyebab perusahaan ini memiliki nilai buku utang yang besar karena perusahaan ini memiliki utang kepada pihak ketiga sebesar Rp 360.351.609.329 pada liabilitas jangka pendeknya dan utang kepada bank yang mencapai Rp 950.149.310.960 pada liabilitas jangka panjangnya.

\section{Bukit Darmo Property Tbk (BKDP)}

Perusahaan ini masuk dalam kondisi perusahaan krisis atau mengalami kesulitan keuangan yang serius dan berpotensi bangkrut. Perusahaan ini memiliki nilai skor Z sebesar 0,56. Perusahaan ini adalah perusahaan yang memiliki kondisi paling parah jika dibandingkan dengan 10 perusahaan lainnya. Dari 5 rasio yang ada, perusahaan ini memiliki nilai yang sangat rendah di 4 rasio yaitu rasio X1, X2, X3 dan X5. Sedangkan rasio $\mathrm{X} 4$ nilainya sudah cukup baik. Perusahaan ini memiliki nilai rasio $\mathrm{X} 1$ sebesar $-0,29$ dengan rata-rata 0,32 , rasio $\mathrm{X} 2$ sebesar $-0,38$ dengan rata-rata 0,43 , rasio $\mathrm{X} 3$ sebesar -0,13 dengan rata-rata 0,14 dan rasio X5 sebesar 0,07 dengan rata-rata 0,20 . Pada rasio $X 1$, perusahaan ini memiliki modal kerja yang bernilai negatif yaitu -Rp 188.115.464.942. Perusahaan ini hanya memiliki aset lancar sebesar Rp 49.322.341.025 dan memiliki liabilitas jangka pendek yang cukup besar yaitu Rp 237.437.805.967. Pada rasio X2, perusahaan ini juga memiliki saldo laba yang bernilai negatif yaitu - Rp 211.955.472.235. Pada rasio X3, lagi-lagi perusahaan ini hanya memiliki nilai EBIT yang negatif yaitu -Rp 28.948.289.175. Lalu pada rasio X5, perusahaan ini memiliki nilai penjualan yang rendah yaitu $\mathrm{Rp}$ 52.413.771.234, sedangkan total asetnya sebesar Rp 785.095.652.150. Berdasarkan informasi pada laporan keuangan, perusahaan ini mengalami kerugian penjualan, Hal ini disebabkan penjualan properti yang mengalami penurunan akibat dari melambatnya pertumbuhan ekonomi Indonesia. Kondisi ini menimbulkan kesangsian substansial mengenai kemampuan Perusahaan untuk melanjutkan usahanya secara berkelanjutan.

\section{Lippo Karawaci Tbk (LPKR)}

Berdasarkan analisis Altman Z-Score, perusahaan ini termasuk dalam kategori perusahaan krisis atau mengalami kesulitan keuangan yang serius dan berpotensi bangkrut. Perusahaan ini memiliki nilai skor Z sebesar 1,43. Jika dilihat dari nilai-nilai rasio yang ada, kondisi kriris tersebut dapat terjadi karena perusahaan ini memiliki nilai rasio X2, X3 dan $\mathrm{X} 4$ yang kecil. Bahkan, nilai rasio X4 perusahaan ini sangat kecil dan merupakan yang terkecil diantara seluruh perusahaan yang ada. Rasio X4 perushaan ini hanya bernilai 0,05 dengan rata-rata dari seluruh perusahaan adalah 1,17 . Rasio X4, perusahaan ini memiliki nilai buku utang yang sangat besar, yaitu mencapai Rp 23.528.544.000.000. Jika diamati, perusahaan ini memiliki total aset sebesar Rp 45.603.683.000.000 dan besar utang perusahaan ini sendiri sudah mencapai setengah lebih dari nilai total asetnya. Dapat dilihat penyebab besarnya nilai buku utang perusahaan ini karena perusahaan ini memiliki utang obligasi yang besarnya mencapai Rp 10.686.105.000.000. Perusahaan melakukan beberapa pendanaan dengan utang obligasi untuk mendukung bisnis Grup. Lalu pada sisi rasio X3 hanya memiliki EBIT sebesar Rp 1.557.747.000.000, sedangkan total asetnya sebesar Rp 45.603.683.000.000. Hal tersebut juga mengakibatkan penentuan saldo laba pada rasio X2 menjadi kecil, yaitu sebesar Rp 7.945.093.000.000. Jika dilihat dari perbandingan laba dan penetapan saldo laba yang dimiliki perusahaan ini berbanding jauh dengan besar total asetnya, sehingga hal mengakibatkan nilai rasio X2 dan X3 menjadi kecil. Peneliti juga mencari informasi yang melatar belakangi kondisi sebenarnya pada perusahaan ini. Berdasarkan informasi yang diperoleh dari berita, menyebutkan bahwa berdasarkan laporan keuangan yang dirilis Lippo Karawaci, Selasa (3/3/2016), laba bersih tahun berjalan yang diatribusikan untuk entitas induk mencapai Rp 535,36 miliar, turun $79 \%$ dibandingkan dengan realisasi sepanjang 2014 
sebanyak Rp 2,55 triliun. Laporan keuangan menunjukkan, pendapatan Lippo Karawaci turun 23,5\% menjadi Rp 8,91 triliun. Pos pendapatan lain-lain juga anjlok 59\% menjadi Rp240 miliar. Di sisi lain, beban perusahaan berkode emiten LPKR itu mencatat kenaikan signifikan. Pos beban lainnya naik 326\% menjadi Rp 270 miliar. Presiden Direktur Lippo Karawaci, Ketut Budi Widjaja, sebelumnya mengatakan indusri properti tahun lalu memang mengalami banyak tekanan sehingga realisasi marketing sales di bawah ekspektasi. Sedangkan pada sisi saham, saham Lippo Karawaci Anjlok 9,55\% dari awal tahun 2016 hingga 31 Desember 2016. (http://market.bisnis.com, 2017)

\section{Simpulan}

Berdasarkan perhitungan rasio-rasio Altman Z-Score dan juga analisis kebangkrutan perusahaan menggunakan metode Altman Z-Score yang telah diuraikan, maka dapat ditarik kesimpulan bahwa perusahaan yang berada pada kondisi krisis adalah Bekasi Asri Pemula Tbk (BAPA), PT Binakarya Jaya Abadi Tbk (BIKA), Bukit Darmo Property Tbk (BKDP), Gowa Makassar Tourism Development Tbk (GMTD) dan Lippo Karawaci Tbk (LPKR).

Lalu untuk perusahaan yang berada pada kondisi grey area adalah Bekasi Fajar Industrial Estate Tbk (BEST), Bumi Serpong Damai Tbk (BSDE) dan Pakuwon Jati Tbk (PWON).

Sedangkan perusahaan yang berada pada kondisi sehat adalah Jaya Real Property Tbk (JRPT), Lamicitra Nusantara Tbk (LAMI) dan Lippo Cikarang Tbk (LPCK).

\section{Referensi}

Arikunto, S. 2010. Prosedur Penelitian Suatu Pendekatan Praktik. Edisi Revisi 2010. Jakarta: PT Rineka Cipta.

Harahap, S. S. 2010. Analisis Kritis Atas Laporan Keuangan. Jakarta: Rajawali Persada

Ikatan Akuntan Indonesia. 2015. Standar Akuntansi Keuangan. Jakarta: Salemba Empat.
Kamaludin. 2011. Manajemen Keuangan, Konsep Dasar dan Penerapannya. Bandung: Maju Mundur.

Setyawan, D. A. 2013. Data dan Metode Pengumpulan Data Penelitian. Surakarta: Jurusan Akupuntur Poltekkes Kemenkes.

Sugiyono. 2010. Metode Penelitian Pendidikan. Bandung: Alfabeta.

Sugiyono. 2012. Metode Penelitian Kombinasi (Mixed Methods). Bandung: Alfabeta.

Toto, P. 2011. Analisis Laporan Keuangan Teori dan Aplikasi. PPM. Jakarta.

Dewi, Rafika sari. 2012. Analisis Penggunaan Z-Score Altman dalam Memprediksi Kebangkrutan Perusahaan Textil dan Garmen di Bursa Efek Indonesia. Skripsi. Jember: Universitas Jember.

Fitriyanti, E. D. dan I. Yunita. 2014. Penggunaan Model Zmijewski, Altman Z-Score dan Springate untuk Memprediksi Kebangkrutan pada Sektor Property \& Real Estate yang Terdaftar di BEI Tahun 2011 2013. Jurnal: Vol.2, No.2 Agustus 2015. Bandung: Universitas Telkom.

Irfan, M. 2014. Analisis Financial Distress dengan Pendekatan Altman Z-Score untuk Memprediksi Kebangkrutan Perusahaan Telekomunikasi. Jurnal : Vol. 3 No. 1. Surabaya: Sekolah Tinggi Ilmu Ekonomi Indonesia (STIESIA) Surabaya.

Maith, Hendry Andres. 2013. Analisis Laporan Keuangan dalam Mengukur Kinerja Keuangan pada PT. Hanjaya Mandala Sampoerna Tbk. Jurnal Riset Ekonomi, Manajemen dan Bisnis dan Akuntansi 1 (3). Universitas Sam Ratulangi Manado.

Meita, E. W. F. 2015. Analisis Penggunaan Metode Altman, Springate, dan Zmijewski dalam Memprediksi Kebangkrutan Perusahaan Pertambangan Batubara Periode 2012-2014. Jurnal Vol: 3 No 3. Surabaya : Universitas Negeri Surabaya.

Peter dan Yoseph. 2011. Analisis Kebangkrutan dengan Metode Z Score Altman, Springate dan Zmijewski pada PT. Indofood Sukses Makmur Tbk Periode 2005 - 2009. Jurnal: Nomor 04 Tahun ke-2 Januari April. Universitas Kristen Maranatha.

Safitra, B. A., Kertahadi. dan S. R. Handayani. 2012. Analisis Metode Altman (z-score) Sebagai Alat Evaluasi Guna Memprediksi Kebangkrutan Perusahaan (Studi pada Industri Rokok yang Terdaftar di BEI Periode 2007 - 2011). Jurnal: Administrasi Bisnis 4 (1). Malang: Universitas Brawijaya.

Septiningsih, Dwi. 2011. Analisis Perbankan Tingkat Kesehatan Perusahaan Menggunakan Metode Altman Z- score dan Analisis Rasio Keuangan (Studi Empiris pada Perusahaan Manufaktur yang Terdaftar di Bursa Efek Indonesia). Skripsi. Jember: Universitas Jember. 